\title{
PELAKSANAAN PENDEKATAN SAINTIFIK DALAM PEMBELAJARAN BAHASA INDONESIA DI SMP NEGERI 15 KOTA BENGKULU
}

\author{
Tika Nopritanti, Ria Ariesta, dan Padi Utomo \\ Program Studi Pendidikan Bahasa Indonesia \\ Jurusan Pendidikan Bahasa dan Seni \\ FKIP Universitas Bengkulu \\ tikanoprianti11@gmail.com
}

\begin{abstract}
Abstrak
Tujuan penelitian untuk mendeskripsikan penyusunan Rencana Pelaksanaan Pembelajaran (RPP) dan proses pelaksanaan pendekatan saintifik dalam pembelajaran bahasa Indonesia di SMP Negeri 15 Kota Bengkulu. Metode penelitian yang digunakan yaitu deskriptif kualitatif. Data dalam penelitian ini adalah Rencana Pelaksanaan Pembelajaran (RPP) buatan guru dan pelaksanaan proses pembelajaran Bahasa Indonesia antara guru dan peserta didik di kelas mengenai pendekatan saintifik di kelas VII B dan VII C SMP Negeri 15 Kota Bengkulu. Teknik pengumpulan data dalam penelitian ini adalah dokumentasi, observasi, dan wawancara. Langkah-langkah analisis data dalam penelitian ini: (1) Membaca Rencana Pelaksanaan Pembelajaran (RPP) buatan Guru, (2) Mengamati Proses Pembelajaran, (3) Melihat Kesesuaian Proses Pembelajaran dengan Rencana Pelaksanaan Pembelajaran (RPP), (4) Menganalisis Data Penelitian Sesuai Permasalahan, dan (5) Interpretasi dan Menarik Kesimpulan. Hasil penelitian ini menunjukkan bahwa (1) Rencana Pelaksanaan Pembelajaran (RPP) yang disusun oleh guru sudah dipersiapkan dengan baik dan menggunakan RPP berbasis saintifik. Rencana Pelaksanaan Pembelajaran (RPP) yang disusun oleh guru telah mencakup: 1) data sekolah, mata pelajaran, dan kelas/semester, 2) kompetensi inti, 3) kompetensi dasar dan indikator, 4) tujuan pembelajaran, 5) materi pembelajaran, 6) metode pembelajaran, 7) media, alat dan bahan, 8) langkah-langkah pembelajaran, dan 9) penilaian. (2) Pada pelaksanaan pembelajaran bahasa Indonesia di kelas VII telah diterapkan pembelajaran menggunakan pendekatan saintifik, dengan langkahlangkah pembelajaran sebagai berikut (1) pendahuluan, (2) inti, dan (3) penutup. Pada kegiatan inti guru telah menerapkan lima langkah pendekatan saintifik yaitu mengamati, menanya, menalar atau mengumpulkan informasi, mencoba, dan mengomunikasikan.
\end{abstract}

Kata kunci: pembelajaran Bahasa Indonesia, pendekatan saintifik

\begin{abstract}
The purpose of the study was to describe the preparation of the Learning Implementation Plan (RPP) and the process of implementing the scientific approach in learning Indonesian in the State Middle School 15 of the City of Bengkulu. The research method used is descriptive qualitative. The data in this study are the Learning Implementation Plan (RPP) made by the teacher and the implementation of the Indonesian learning process between the teacher and students in the class regarding
\end{abstract}


text-based learning in class VII B and VII C of SMP Negeri 15 Kota Bengkulu. Data collection techniques in this study are documentation, observation, and interviews. The steps of data analysis in this study: (1) Reading the Learning Implementation Plan (RPP) made by the Teacher, (2) Observing the Learning Process, (3) Looking at the Conformity of the Learning Process with the Learning Implementation Plan (RPP), (4) Analyzing Research Data In Accordance with Problems, and (5) Interpretation and Interesting Conclusions. The results of this study indicate that (1) the Learning Implementation Plan (RPP) prepared by the teacher is well prepared and uses scientific-based lesson plans. The Learning Implementation Plan (RPP) prepared by the teacher includes: 1) school data, subjects, and classes / semesters, 2) core competencies, 3) basic competencies and indicators, 4) learning objectives, 5) learning material, 6) learning methods, 7) media, tools and materials, 8) learning steps, and 9) assessment. (2) In the implementation of Indonesian language learning in class VII learning has been applied using a scientific approach, with learning steps as follows (1) introduction, (2) core, and (3) closing. At the core activity the teacher has implemented a five-step scientific approach, namely observing, asking, reasoning or gathering information, trying, and communicating.

\section{Keywords: Learning Indonesian, Scientific Approach}

\section{PENDAHULUAN}

Undang-undang Republik Indonesia Nomor 20 Tahun 2001 mendefinisikan pendidikan adalah usaha sadar dan terencana untuk mewujudkan suasana belajar dan proses pembelajaran agar peserta didik secara aktif mengembangkan potensi dirinya. Tujuan pendidikan nasional adalah mengembangkan kemampuan dan membentuk watak serta peradaban bangsa yang bermartabat dalam rangka mencerdaskan kehidupan bangsa, berkembangnya potensi peserta didik agar menjadi manusia yang beriman, berakhlak mulia, sehat, berilmu, cakap, kreatif, mandiri, demokratis, dan bertanggung jawab (Kemendikbud, 2014). Salah satu upaya pemerintah untuk meningkatkan kualitas pendidikan adalah penyempurnaan kurikulum beserta perangkat pendukungnya.

Dalam sejarah pendidikan di Indonesia sudah beberapa kali diadakan perubahan dan perbaikan kurikulum, mulai dari kurikulum Rentjana Pembelajaran tahun 1947 sampai saat ini kurikulum terbaru yakni Kurikulum 2013 (Kurniasih, 2014:4).Perbaikan dan penyempurnaan kurikulum ini memang sangat penting dilakukan mengingat pada abad 21 saat ini, ilmu pengetahuan, teknologi dan komunikasi semakin berkembang, sehingga kebutuhan perkembangan dalam dunia pendidikan pun harus dilakukan. Perubahan kurikulum terbaru yaitu Kurikulum 2013 yang merupakan penyempurnaan dari Kurikulum Tingkat Satuan Pendidikan (KTSP). Penerapan Kurikulum 2013 bertujuan untuk membentuk peserta didik yang berkarakter, kreatif, dan inovatif yang dapat menjadi kekuatan bangsa dimasa yang akan datang.

Penerapan Kurikulum 2013 ini telah dilaksanakan dibanyak sekolah yang ada di Indonesia, termasuk sekolah-sekolah di Provinsi Bengkulu. Penerapan Kurikulum 2013 di Provinsi Bengkulu mendapat respon baik dari guru dan masyarakat sehingga banyak sekolah yang 
melaksanakan Kurikulum 2013 dimulai dari tahun 2013 hingga sekarang. Namun, kurangnya pemahaman tentang Kurikulum 2013 membuat penerapan Kurikulum 2013 di sekolah-sekolah yang ada di Provinsi Bengkulu belum berjalan secara maksimal terutama sekolah yang berada di daerah terpencil.

Salah satu hal pokok dalam Kurikulum 2013 adalah menekankan pada pembelajaran siswa aktif. Dalam hal ini, peran guru sangat signifikan dalam upaya mensukseskan tujuan Kurikulum 2013 tersebut. Implementasi Kurikulum 2013 secara benar dipercaya dapat mengatasi permasalahan sumber daya manusia di negara Indonesia (Sani, 2015:5).Untuk dapat mencapai tujuan yang diharapkan dari penerapan Kurikulum 2013 tersebut, tentunya diperlukan sebuah pendekatan yang sesuai.Pendekatan yang sesuai untuk mencapai tujuan tersebut adalah pendekatan saintifik.

Daryanto (2014:51) menyatakan bahwa pembelajaran dengan pendekatan saintifik adalah proses pembelajaran yang dirancang sedemikian rupa agar peserta didik secara aktif mengkonstruksi konsep, hukum atau prinsip melalui tahapantahapan mengamati (untuk mengidentifikasi atau menemukan masalah), merumuskan masalah, mengajukan atau merumuskan hipotesis, mengumpulkan data dengan berbagai teknik, menganalisis data, menarik kesimpulan dan mengomunikasikan konsep, hukum atau prinsip yang "ditemukan". Jadi dalam Kurikulum 2013 memfokuskan pembelajaran pada pendidikan, sehingga guru harus menerapkan pendekatan saintifik dalam pelaksanaan pembelajaran sesuai dengan komponen proses pendekatan saintifik tersebut.

Penerapan pendekatan saintifik dalam Kurikulum 2013 berlaku untuk semua materi dan semua mata pelajaran.
Termasuk mata pelajaran bahasa Indonesia. Pembelajaran bahasa Indonesia diarahkan untuk meningkatkan kemampuan peserta didik untuk berkomunikasi dengan bahasa Indonesia yang baik dan benar, baik secara lisan maupun tulis, serta menumbuhkan apresiasi terhadap hasil karya kesastraan manusia Indonesia. Mata pelajaran bahasa Indonesia mencakup komponen kemampuan berbahasa dan kemampuan bersastra yang meliputi aspek-aspek mendengarkan, berbicara, membaca, dan menulis (Masrup, 2012:144). Pembelajaran berbasis teks inilah yang digunakan sebagai dasar pengembangan kompetensi dasar mata pelajaran bahasa Indonesia ranah pengetahuan dan keterampilan dalam Kurikulum 2013.

Berdasarkan hal tersebut, peserta didik dituntut untuk sampai ke tahap mengapresiasi yaitu mampu menciptakan atau memproduksi. Pada pembelajaran berbasis teks yang ada di sekolah saat ini banyak yang belum sampai pada tahap mereaksi tersebut, seharusnya peserta didik berpikir kritis untuk sampai pada tahap menciptakan atau memproduksi. Agar peserta didik lebih aktif dan sampai pada tahap tersebut, melalui pendekatan saintifik yang disarankan dalam Kurikulum 2013 diharapkan tercapainya tujuan pembelajaran berbasis teks.

Pemaparan di atas menjadi alasan peneliti mengangkat sebuah judul penelitian yaitu Pembelajaran Bahasa Indonesia Menggunakan Pendekatan Saintifik di Kelas VII SMP Negeri 15 Kota Bengkulu.

\section{METODE}

Jenis penelitian ini adalah penelitian kualitatif dan metode yang digunakan yaitu deskriptif kualitatif. Data dan sumber data berupa Rencana Pelaksanaan Pembelajaran (RPP) buatan guru beserta komponen Rencana Pelaksanaan Pembelajaran (RPP) 
dan catatan pelaksanaan proses pembelajaran Bahasa Indonesia antara guru dan peserta didik di kelas mengenai pembelajaran berbasis teks yang menggunakan pendekatan saintifik di kelas VII B dan VII C SMP Negeri 15 Kota Bengkulu. Data dikumpulkan dengan cara dokumentasi, observasi, dan wawancara.

Teknik analisis data yang digunakan dalam adalah dengan menyusun langkah spesifikasi sebagai berikut. (i) Membaca Rencana Pelaksanaan Pembelajaran (RPP) buatan Guru. (ii) Setelah membaca Rencana Pelaksanaan Pembelajaran (RPP), peneliti melakukan pengamatan langsung proses pembelajaran bahasa Indonesia di kelas. (iii) Melihat Kesesuaian Proses Pembelajaran dengan Rencana Pelaksanaan Pembelajaran (RPP). (iv) Menganalisis Data Penelitian Sesuai Permasalahan. (v) Interpretasi dan Menarik Kesimpulan.

Validasi pada penelitian ini menggunakan teknik triangulasi sumber dan teori. Triangulasi sumber dilakukan dengan membandingkan hasil wawancara yang dilakukan dengn guru bahasa Indonesia dan hasil pengamatan yang dilakukan peneliti kemudian membandingkan hasil wawancara dengan suatu dokumen yang berkaitan dengan berupa RPP.

\section{HASIL PENELITIAN DAN PEMBAHASAN Hasil}

Hasil penelitian ini menunjukkan perencanaan dan pelaksanaan pembelajaran bahasa Indonesia menggunakan pendekatan saintifik di SMP Negeri 15 Kota Bengkulu yaitu bertujuan untuk mendeskripsikan pelaksanaan pembelajaran bahasa Indonesia menggunakan pendekatan saintifik di SMP Negeri 15 Kota Bengkulu pada kelas VII B dan kelas VII C. Penelitian ini mendeskripsikan perencanaan yang dilakukan guru sebelum kegiatan pembelajaran dan mendeskripsikan pelaksanaan pembelajaran dengan menggunakan pendekatan saintifik.

Pada kegiatan pembelajaran Bahasa Indonesia di SMP Negeri 15 Kota Bengkulu kelas VII B (RPP 2 (KD 3.15 dan KD 4.15)) dan VII C (RPP 1 (KD 3.14 dan KD 4.14)) sebelum melaksanakan kegiatan pembelajaran di kelas seorang guru perlu mempersiapkan atau merancang suatu proses pembelajaran dalam bentuk Rencana Pelaksanaan Pembelajaran (RPP). RPP yang dirancang oleh guru pada pertemuan ini berdasarkan RPP 1 (KD 3.14 (menelaah unsur-unsur dan kebahasaan dari surat pribadi dan surat dinas yang dibaca dan didengar) dan KD 4.41 (menulis surat pribadi dan dinas untuk kepentingan resmi dengan memperhatikan struktur teks, kebahasaan, dan isi)), RPP 2 (KD 3.15 (menemukan unsur-unsur dari buku fiksi dan nonfiksi yang dibaca) dan KD 4.15 (membuat peta pikiran/rangkuman alur tentang isi buku nonfiksi/buku fiksi yang dibaca.

RPP yang disusun oleh guru telah terdapat Kompetensi Inti (KI) mulai dari KI 1 sampai KI 4. KI 1 berkaitan dengan sikap spiritual, KI 2 berkaitan dengan sikap sosial, $\mathrm{KI} 3$ berkaitan dengan pengetahuan, dan KI 4 berkaitan dengan keterampilan. Kompetensi inti 1 ranah sikap aspek spiritual dan Kompetensi Inti 2 sikap sosial tidak diajarkan tetapi diintegrasikan dalam Kompetensi Inti 3 ranah kognitif dan Kompetensi Inti 4 psikomotor. Keempat KI ini sudah tertulis pada RPP buatan guru.

Selain Kompetensi Dasar dan Kompetensi Inti, RPP yang dibuat oleh guru juga mencakup komponen RPP yang lain yaitu (1) identitas sekolah, mata pelajaran, kelas/semester, materi pokok, dan alokasi waktu; (2) tujuan pembelajaran;(3)materi pembelajaran; (4) metode pembelajaran; (5) media pembelajaran; (6) sumber belajar; (7) langkah-langkah pembelajaran; dan (8) penilaian hasil belajar. 
Perencanaan alokasi waktu pada RPP buatan guru RPP 1 (KD 3.14) yaitu 12 jam pelajaran dalam lima kali pertemuan. Pada pelaksanaannya pertemuan pertama dan pertemuan kedua dilaksanakan masingmasing tiga jam pelajaran, pertemuan ketiga, pertemuan keempat, dan pertemuan kelima dilaksanakan masingmasing dua jam pelajaran. Dan RPP 1 (KD 4.14) yaitu 9 jam pelajaran dalam tiga kali pertemuan. Pada pelaksanaannya pertemuan pertama, pertemuan kedua, dan pertemuan ketiga dilaksanakan masing-masing tiga jam pelajaran. Pelaksanaan pembelajaran di kelas RPP 1 dilaksanakan tidak sesuai dengan Rencana Pelaksanaan Pembelajaran yang telah dibuat oleh guru. RPP 1 (KD 3.14 dan KD 4.14) dilaksanakan dalam lima kali pertemuan. Alokasi waktu yang direncanakan pada RPP 2 yang telah dibuat oleh guru adalah delapan jam pertemuan dilaksanakan dalam dua kali pertemuan masing-masing empat jam pelajaran. Namun, pada pelaksanaan pembelajaran dilakukan pada tiga kali pertemuan. Setiap pertemuan masing-masing tiga jam pelajaran untuk menyelesaikan materi.

Tujuan dari RPP 1 yang akan dicapai yaitu menjelaskan perincian unsur dan struktur surat pribadi dan surat dinas, merencanakan penulisan surat pribadi dan surat dinas. Berdasarkan tujuan tersebut siswa diminta mampu menjelaskan secara mandiri dan rinci unsur dan strukur surat pribadi dan surat dinas, dan mampu menulis surat pribadi dan surat dinas dengan memperhatikan kelengkapan struktur.

Tujuan pembelajaran pada RPP 2 yang akan dicapai yaitu membuat komentar tentang buku fiksi dan buku nonfiksi. Berdasarkan tujuan tersebut siswa diminta mampu berkomentar tentang buku fiksi dan buku nonfiksi. Pada kegiatan pembelajaran RPP 1 dan RPP 2 tidak hanya bersifat teoritis namun mengarah pada praktik atau keterampilan.

Materi pembelajaran yang digunakanpada RPP 1 dan 2 adalah materi pengetahuan dan materi keterampilan yang digunakan untuk materi pembelajaran reguler. Materi untuk remedial juga menggunakan materi di atas, yang berbeda adalah materi pembelajaran pengayaan.

Metode yang digunakan RPP 1 dan RPP 2 adalah metode inkuiri, diskusi, tanya jawab, penugasan, dan presentasi. Pemilihan metode pembelajaran disesuaikan dengan situasi dan kondisi siswa, serta karakteristik dari setiap indikator dan kompetensi yang hendak dicapai pada setiap mata pelajaran. Pada pelaksanaan kegiatan pembelajaran guru sudah menerapkan pendekatan santifik dan metodenya dengan cukup baik.Pada RPP buatan guru kegiatan pembelajaran RPP 1 menggunakan bahan ajar berupa; 1) buku, 2) infokus, 3) contoh langkah penyusunan surat pribadi dan surat dinas, 4) contoh variasi judul pada surat pribadi dan surat dinas, 5) contoh variasi identifikasi, 6) contph variasi rincian bagian. Sedangkan pada RPP buatan guru pada RPP 2 menggunakan bahan ajar sebagai berikut: 1) buku fiksi dan nonfiksi, infokus, 2) contoh unsur-unsur buku fiksi, 3) contoh unsur-unsur buku non fiksi, 4) contoh persamaan dan perbedaan unsur buku non fiksi.

Berdasarkankegiatan pembelajaran RPP 1 dan RPP 2 yang telah dibuat oleh guru bahan ajar yang menggunakan infokus tidak diterapkan karena tidak semua kelas memiliki aliran listrik langsung ke kelasnya. Sebagai gantinya guru telah menyiapkan bahan ajar berupa potongan contoh-contoh surat pribadi dan surat dinas sebagai bahan ajar yang digunakan pada proses belajar mengajar di kelas.

Langkah-langkah pembelajaran yang menggunakan pendekatan saintifik 
berdasarkan RPP yang telah dibuat oleh guru pada kegiatan pembelajaran RPP 1, RPP 2, dan RPP 3 memuat tiga kegiatan yaitu kegiatan pendahuluan, kegiatan inti, dan kegiatan penutup. Pada kegiatan pendahuluan diawali dengan mengucapkan salam, berdoa, mengecek kehadiran siswa, dan mengondisikan kelas sebelum memulai kegiatan inti. Kemudian menyampaikan tujuan dari pembelajaran yang akan diajarkan.

Kegiatan inti pada RPP 1 pertemuan pertama yang menggunakan pendekatan saintifik, pada langkah-langkah pembelajaran terdapat tiga kegiatan saintifik yaitu mengamati, menalar, dan mencoba. Kegiatan saintifik yang terimplementasi pada RPP 1 adalah kegiatan mengamati (Mengamati tabel struktur surat pribadi dan surat dinas), sedangkan kegiatan menalar dan mencoba tergambar pada aktivitas siswa.

Pertemuan kedua langkah-langkah pembelajaran yang menggunakan pendekatan saintifik yaitu mengamati, menanya, menalar, dan mengomunikasikan. Kegiatan saintifik yang terimplementasi pada RPP 1 adalah kegiatan mengamati (Mengamati urutan kalimat acak (bagian struktur yang acak)) dan menanya (Mempertanyakan cara mengurutkan), kegiatan menalar dan mengomunikasikan hanya tegambar pada aktivitas siswa.

Pertemuan ketiga terdapat tiga pendekatan saintifik yaitu mengamati, menalar, dan mencoba. Kegiatan saintifik yang teimplementasi pada langkah-langkah pembelajaran adalah kegiatan mengamati (Membaca dan mengamati contoh kesalahan penggunaan kata, kalimat, tanda baca/ejaan. Keiatan menalar dan mencoba tidak terimplementasi pada RPP 1 melainkan tergambar pada aktivitas siswa.

Pada pertemuan keempat kegiatan pembelajaran yang dibuat oleh guru tedapat empat langkah-langkah saintifik yaitu mengamati, menanya, menalar, dan mengomunikasikan. Kegiatan saintifik yang terimplementasi adalah keiatan mengamati (Mengamati kata-kata kunci), menanya (Mempertanyakan bagaimana cara mengembangkan teks dari kata kunci), dan mnegomunikasikan (Mengomunikasikan hasil). Sedangkan kegiatan menalar tidak terimplementasi pada RPP 1 melainkan tegambar pada aktivitas siswa.

Pertemuan kelima RPP 1 terdapat empat kegiatan saintifik yaitu mengamati, menalar, mencoba dan mengomunikasikan. Kegiatan saintifik yang terimplementasi yaitu keiatan mengamati (Mengamati baian-bagian yang tidak lengkap), dan mengomuniksaikan (Mengomunikasikan hasil). Pada kegiatan menalar dan mencoba tidak terimplementasi pada RPP 1 namun tergambar pada aktivitas siswa.

Selanjutnya kegiatan inti pada RPP 2 pertemuan pertama yang menggunakan pendekatan saintifik. Pada langkah-langkah pembelajaran terdapat empat kegiatan saintifik yaitu mengamati, menanya, menalar, dan mencoba. Pendekatan saintifik yang terimplementasi pada langkah-langkah pembelajaran RPP 2 yaitu mengamati (Mengamati masalah/menulis garis besar isi surat dan tujuan surat), dan menanya (Mempertanyakan langkah membuat surat pribadi dan surat dinas dengan mengamati objek/masalah). Sedangkan kegiatan menalar dan mencoba tidak terimplementasi pada RPP 2 melainkan tegambar pada aktivitas siswa.

Pertemuan kedua pada langkah-langkah pembelajaran terdapat empat keiatan saintifik yaitu mengamati, menalar, mencoba dan mengomunikasikan. Kegiatan saintifik yang terimplementasi pada RPP 2 adalah mengamati (Mengamati contoh surat). Sedangkan keiatan menalar, mencoba, dan mengomunikasikan tidak terimplementasi pada RPP 2 melainkan tegambar melalui aktivitas siswa. 
Pertemuan ketiga kegiatan pembelajaran yang dibuat oleh guru terdapat empat langkah-langkah saintifik yaitu mengamati, menanya, menalar, dan mencoba. Kegiatan saintifik yang terimplementasi pada RPP yaitu mengamati (Mengamati contoh kesalahan perbaikannya) dan menanya (Menanya bagaimana yang salah, mengapa). Sedangkan kegiatan menalar dan mencoba tidak terimplementasi pada langkahlangkah pembelajaran melainkan tergambar pada aktivitas siswa.

Selanjutnya kegiatan inti RPP 3 pertemuan pertama yang menggunakan pendekatan saintifik. Pada kegiatan langkah-langkah pembelajaran yang dibuat oleh guru terdapat tiga langkah-langkah saintifik yaitu mengamati, menanya, dan menalar. Ketiga langkah-langkah saintifik tidak terimplementasi pada RPP 3 melainkan hanya tergambar pada aktivitas siswa.

Berdasarkan kompetensi dasar yang akan dicapai pada RPP 1 dan RPP 2 yang telah dibuat oleh guru teknik penilaian menggunakan teknik tes tulis penugasan dan portofolio. Penugasan diberikan melalui Pekerjaan Rumah atau tugas yang dikerjakan secara individu dan kelompok. Setiap tugas yang dikerjakan oleh siswa akan dinilai oleh guru baik yang teoritis maupun praktik. Hasil penilaian akan dimasukkan ke dalam buku nilai guru. Berdasarkan RPP yang dibuat oleh guru, pada penilaian tidak terdapat rubrik penilaian yang menjadi tolak ukur dalam pemberian nilai kepada siswa. Pada RPP tersebut hanya terdapat teknik penilaian dan bentuk tugas yang akan diberikan kepada siswa.

\section{Pembahasan}

Berdasarkanpelaksanaanpembelajaran di SMPN 15 Kota Bengkulu yang menggunakan pendekatan saintifik terbagi ke dalam lima langkah kegiatan pembelajaran.

Langkah-langkah pembelajaran dengan menggunakan pendekatan saintifik diuraikan sebagai berikut.

Pelaksanaan kegiatan pembelajaran yang menggunakan pendekatan saintifik diawali dengan kegiatan mengamati. Guru membuka secara luas dan bervariasi kesempatan siswa untuk melakukan pengamatan melalui kegiatan melihat, menyimak, mendengar, dan membaca.

Berdasarkan hasil observasi pada saat pembelajaran RPP 1 (kelas VII C) dan RPP 2 (kelas VII B) di kelas, dalam kegiatan pembelajaran di kelas tidak semua siswa melakukan kegiatan menanya. Dalam kegiatan menanya, guru memberikan kesempatan kepada siswa secara luas untuk bertanya mengenai apa yang sudah dijelaskan, dibaca, dan dilihat. Melalui kegiatan bertanya, dikembangkan rasa ingin tahu siswa.

Kegiatan selanjutnya menalar, siswa mengolah informasi yang dikumpulkan untuk menemukan antara keterkaitan satu informasi dengan informasi lainnya, kemudian mengambil berbagai kesimpulan dari informasi yang ditemukan melalui kegiatan menalar ini. Pada kegiatan menalar di kelas VII B, siswa diminta oleh guru mengomentari hasil kerja kelompok siswa yang berada di depan kelas.

Kegiatan mencoba yang dilakukan di kelas VII B dan kelas VII C kegiatan mengamati dan menanya kembali muncul pada kegiatan mencoba. Siswa kembali mengamati buku fiksi dan buku nonfiksi. Setelah melakukan pengamatan siswa menggali informasi dari pengamatannya dan siswa mulai mencoba membuat tugas yang diberikan guru.

Kegiatan berikutnya dalam pembelajaran yang menggunakan pendekatan saintfiik adalah mengomunikasikan. Kegiatan mengamati, menanya, mencoba/mencari informasi,dan mengasosiasikan/menala kembali muncul 
pada kegiatan mengomunikasikan. Kegiatan mengomunikasikan dilakukan secara individu maupun kelompok.

Berdasarkan hasil penelitian pada langkah-langkah pembelajaran yang dibuat dalam RPP 1, RPP 2, dan RPP 3 hanya terdapat satu kegiatan pendahuluan dan kegiatan penutup. Pada pelaksanaannya kegiatan pendahuluan dan kegiatan penutup di kelas VII B dan VII C kegiatan pendahuluan dan kegiatan penutup pada setiap pertemuan sudah dilaksanakan. Pada RPP 1 dan RPP 2 langkah-langkah kegiatan pembelajaran yang dibuat oleh guru, langkah-langkah pendekatan saintifik tidak muncul secara bersamaan pada setiap kali pertemuan. Setiap pertemuan muncul tiga atau empat pendekatan saintifik dan terimplementasi pada RPP dan aktivitas siswa. Pada RPP 3 kegiatan mengomunikasikan tidak terimplementasi dan tidak tegambar melalui aktivitas siswa.

Pembelajaran yang dilakukan dengan menggunakan pendekatan saintifik ini berpusat pada siswa. Guru hanya berperan sebagai fasilitator dan motivator. Guru perlu memotivasi siswa untuk berkonsentrasi pada petunjuk-petunjuk atau karakteristik yang akan siswa deskripsikan dan tidak hanya menebak atau menduga saja. Pada pembelajaran bahasa Indonesia menggunakan pendekatan saintifik, siswa diminta agar mampu mengimplementasikan kelima langkahlangkah pembelajaran itu pada saat pembelajaran di kelas.

Pada pelaksanaan kegiatan pembelajaran yang menggunakan pendekatan saintifik diawali dengan kegiatan mengamati. Guru membuka secara luas dan bervariasi kesempatan siswa untuk melakukan pengamatan melalui kegiatan melihat, menyimak, mendengar, dan membaca. Pada kegiatan menanya, guru memberikan kesempatan kepada siswa untuk merumuskan sebuah pertanyaan mengenai apa yang telah siswa amati sebelumnya dengan menyimak, membaca, melihat, dan mendengar.Pada kegiatan menalar ini kegiatan mengamati, dan menanya kembali terjadi. Siswa kesulitan dalam menalar sehingga mereka mengamati kembali buku dan catatan sebelumnya, dan beberapa siswa kembali bertanya kepada guru untuk mengetahui maksud yang tidak mereka ketahui. Setelah mendapatkan penjelasan dari guru, siswa mampu membuat kesimpulan untuk menganalisis dan membandingkan apa yang diamati.Kemudian secara bersama antara guru dan siswa dengan mengumpulkan data dengan berbagai teknik, hingga siswa mampu mengomunikasikannya.Pembelajaran

bahasa Indonesia yang menggunakan pendekatan saintifik di SMP Negeri 15 Kota Bengkulu dapat meningkatkan aktivitas belajar siswa pada saat pembelajaran di kelas. Dengan menggunakan pendekatan saintifik ini diharapkan mampu menumbuh kembangkan karakter siswa.

\section{PENUTUP}

\section{Kesimpulan}

Berdasarkan hasil penelitian dan pembahasan dapat disimpulkan bahwa perencanaan pembelajaran yang disusun oleh guru bahasa Indonesia kelas VII di SMP Negeri 15 Kota Bengkulu, pada RPP yang telah disusun oleh guru langkah-langkah pembelajaran yang dibuat tidak terimplementasi dengan baik pada langkahlangkah pendekatan saintifik. Pada RPP kegiatan mengomunikasikan tidak dicantumkan baik secara eksplisit maupun melalui aktivitas siswa.

Pada pelaksanaan pembelajaran bahasa Indonesia telah diterapkan lima langkah pendekatan saintifik dalam proses kegiatan pembelajaran diantaranya yaitu pada kegiatan pendahuluan, inti, dan penutup. Pada kegiatan inti proses pembelajaran di kelas telah menggunakan pendekatan saintifik yaitu mengamati, 
menanya, menalar, mencoba, dan mengomunikasikan. Pada kegiatan pembelajaran setiap pertemuan, lima langkah pendekatan saintifik tidak muncul secara bersamaan. Pada kegiatan menanya tidak semua siswa aktif bertanya hanya ada beberapa siswa yang bertanya. Berdasarkan langkah-langkah pembelajaran yang telah dilakukan dengan pendekatan saintifik memberikan kesempatan siswa untuk mencapai Kompetensi Inti 1, Kompetensi Inti 2, Kompetensi Inti 3, dan Kompetensi Inti 4 sesuai dengan tuntutan Kurikulum 2013.

\section{Saran}

Berdasarkan hasil penelitian dan kesimpulan maka penulis menyarankan.

1. Bagi guru, pada RPP yang telah disusun menggunakan pendekatan saintifik sebaiknya dapat dibuat lebih lengkap dan pada langkah-langkah pembelajaran dikegiatan inti pendekatan saintifik lebih diperjelas.

2. Bagi siswa, sebaiknya dalam kegiatan proses pembelajaran di kelas hendaknya siswa lebih aktif dan berani terutama pada saat pengajuan pertanyaan baik siswa yang bertanya maupun menjawab pertanyaan guru.

3. Bagi sekolah, dapat mendukung proses pembelajaran dengan baik. Dengan menyediakan media dan sumber belajar lebih banyak lagi agar siswa lebih aktif.

\section{DAFTAR PUSTAKA}

Daryanto. 2014. Pendekatan Pembelajaran Saintifik. Yogyakarta: Gava Media.

Kemendikbud. 2014. Permendikbud No.58 Tahun 2014 Tentang Kurikulum 2013 Sekolah Menengah Pertama/ Madrasyah Tsanawiah. Jakarta: Kementerian Pendidikan dan Kebudayaan.

Kurniasih, Imas, Barlin Sani. 2014. Sukses Mengimplementasikan Kurikulum 2013. Jakarta: Kata Pena.

Masrup, Moch. 2012. Jurnal Pendidikan Bahasa dan Satra Indonesia. (Htpp:/jurnal.unnes.ac.id/sju/index. php/seloka diakses 18 Maret 2018).

Sani, Ridwan Abdullah. 2015. Pembelajaran Saintifik untuk Implementasi Kurikulum 2013. Jakarta: Bumi Aksara. 